\title{
INFORMATION EXTERNALITIES IN OIL AND GAS LEASING
}

\author{
JEFFREY J. LEITZINGER and JOSEPH E STIGLITZ*
}

This paper discusses the theory and measurement of information externalities in oil and gas leasing. A study of leases issued in the Gulf of Mexico reveals significant positive information externalities resulting from prior development of adjoining leases. According to a recent court decision, these effects provide an added consideration in the determination of a "fair and equitable" division of revenues from federal tracts adjoining state lands, as required by the 1978 amendments to the Outer Continental Shelf Lands Act.

\section{INTRODUCTION}

Advocates of using economic analysis to guide public policy are often frustrated by the difficulties of tying theory to real-world experience. Two areas in which the problem is especially severe are externalities and informational effects. Each encompasses important real-world phenomena; yet, both have proven elusive to measure. Is the information conveyed by an aspirin brand name worth five times the generic price? When your neighbor neglects his lawn, your property value declines. If the courts elect to enforce a right to "normal" lawn maintenance, how would it measure the extent to which the neighbor failed to comply with standards of "normal" lawn maintenance, and how much should the neighbor be forced to pay?

Both of these empirical problem areas came together recently in a lawsuit brought by the state of Texas against the Department of Interior.' Briefly, the state argued:

State development of oil-and-gas-producing lands adjoining the federal outercontinental shelf (OCS) produced valuable information concerning deposits underlying both state and federal lands.

In four federal lease sales conducted in the late 1970s, this information externality generated hundreds of millions of dollars in higher cash bonuses, royalties, and taxes.

In the course of its investigation, the state developed evidence pointing to the existence of positive externalities arising from information production. In fact, the state argued, more than half of the cash bonuses received by the federal government in three years of lease sales could be attributed to prior state leasing activity. In a recent decision, the federal district court accepted the state's argument, and awarded the state $\$ 215$ million as its fair and equitable share of the enhancement brought about in federal leases by information produced through prior state development.

The general subject of the state's contentions has been discussed frequently in the

-Dr. Leitzinger is a senior consultant with National Economic Research Associates, Inc., Los Angeles, California. Dr. Stiglitz is a professor of economics at Princeton University. This paper is an abbevinted version of a more comprehensive discussion of the problem presented at the Western 5 conomic A vociation International conference in Seattle, July 1983. It contains no formal analysis of bidding behavios, and only a limited discussion of the social returns to information, of the consequences of filling to intermaline externalities, and of alternative remedies.

1. Texas v. Watt et al. 

tion externalities." Some have suggested that private supply of information results in underproduction. ${ }^{3}$ Contrary to common perception (and to the state's position) that information is a good, some authors have argued that increased information distributed unevenly among prospective bidders reduces competition, and thus ultimately imposes a cost on the lessor." In any case, little has been done by way of actually measuring informational effects.

The body of this paper is divided into two sections. Section II contains the economic theory of information as it relates to oil and gas leasing, including descriptions of potential external effects. Section III contains empirical results showing the existence of large positive information externalities.

\section{THEORY OF INFORMATION EXTERNALITIES}

\section{A. The Value of Information}

As an input to the production of oil and gas, information ranks in importance with drilling equipment, pipelines and platforms. The figures in table 1 show shares of total production cost derived from projections by the U.S. Department of Interior for selected cost categories in four OCS lease sales during the late 1970s.

TABLE 1

Cost Shares of Selected Expense Categories

\begin{tabular}{lc} 
Expense Category & Percent of Total \\
Exploration & $5.9 \%$ \\
Development & 3.2 \\
Pipelines & 3.0 \\
Platforms & 6.1 \\
Cash Bonuses & 37.6 \\
Royalties & 44.2 \\
\hline
\end{tabular}

SOURCE: Department of Interior, Pre-Sale Environmental Impact Statements, Lease Sale 58, 58А, 62, A66.

The 5.9-percent exploration component reflects the cost of producing information. It exceeds the cost share for pipelines and is about equal to that for platforms. Moreover, this figure underestimates the total outlay for information. These,figures represent shares of nominal expense. Since exploration expenditures occur early in the lifetime of a lease, their share of cost measured by present value is certainly higher. Moreover, these figures represent only those costs incurred after the time of the lease sale. In preparation for a sale, prospective bidders reportedly devote tens of thousands of man hours to preparing bid strategies - i.e., to gathering and interpreting information concerning prospective tracts.

Despite this considerable expense, the business of oil and gas production remains largely uncertain. One in seven tracts leased by the federal government in the Gulf

2. See, e.g., Mead, Sorensen, and Moseidjord (1982, pp. 30-31); Leland, Nordgaard, and Pearson (1975, ch. 5); Miller (1973, p. 415); Stiglitz (1975, p. 94); and Peterson (1975, pp. 101-113).

3. See Miller (1973, p. 415) and Stiglitz (1975, p. 94).

4. See Wilson (1967, pp. 816-820) and Mead, Sorensen, and Moseidjord (1982, p. 35). 

the Gulf region suggests that the success ratio is undoubtedly lower in other regions of the country.

The high demand for information is in part due to this uncertainty and to specific features of the industry technology. It is said that you never really know what you have until you sink your first wells. However, the development expense required to sink (or spud) initial wells can run as high as $\$ 7$ million per well. "If nothing is found, little of the original investment can be recovered. Information is valuable because it reduces the frequency of dry tracts and, as a result, the frequency of unproductive development expense.

Better information also acts to reduce the cost of development for productive tracts. It allows operators to bring producing wells on stream at an earlier date, at lower cost. In State of Texas $t$. Watt, one industry consultant familiar with production technology testified that specific information concerning the geology of underlving reservoirs could save as much as 20 percent in development costs and one-totwo years in development time.: At a 10-percent discount rate, that time saving amounts to an additional saving of nearly 20 percent in development cost per dollar of present production value.

Finally, better information reduces risk. With better information, the owner faces a single known outcome from the development of his land, not a range of possible results. To the extent that owners are risk averse, added information increases their welfare.

These effects, all of which are positive, constitute the major impacts of information on an integrated owner/producer. ${ }^{8}$ Information is valuable. It increases the present value of hydrocarbon deposits, both to the owner and to society.

B. Information and Competitive Bidding

In most cases, oil and gas are not produced by integrated owner/producers. Often, the right to produce hydrocarbons is auctioned among prospective producers by the owner (typically the federal government or a state government). Lease terms usually consist of fixed ad valorem royalties combined with cash bonuses deter mined through sealed bid auctions. The previous subsection discusses informational effects on development cost and risk, both of which serve to increase tract values. Cashbonus auctions introduce an additional set of informational effects-some of which are positive, some negative.

Consider first the value of information to individual bidders. Cash-bonus auctions force bidders to pay for a tract while they are still uncertain as to its eventual value. Uncertainty introduces a range of possible outcomes into the bidding process. One can underestimate the value of a lease, be outbid by competitors (with more accurate estimates), and end up closed out of individual lease sales. On the other hand, a company can overestimate the value of a tract and win the lease, only to lose millions as a victim of the so-called "winner's curse."

5. Minerals Management Service (1982) data on lease production.

6. American Petroleum Institute (1981, table 53).

7. Direct testimony of P. G. Von Tungelen in Texas c. Watt et al.

8. There are other important impacts excluded here for the sake of brevity. For instance, better information improves scheduling of resource development, inasmuch as better information enables owners to identify and lease first the low cost producing tracts. 
At the same time, if the competition underestimates the value of a tract, one can make large profits by bidding just above the competition. Alternatively, one can leave those profits on the table by bidding the correct value, i.e., by significantly outbidding the competition.

To any one bidder, the value of additional information (not also provided to his competition) is high. He can use it to help avoid being closed out and/or to reduce the amount of money left on the table.

So far, the discussion has focused on private information. Leasing activity also can be expected to increase the general level of information. From the standpoint of this paper, the important difference between private and general information distribution is the incidence of the effects. The (positive or negative) benefit associated with added general information (as opposed to private information), whatever the source, goes to the lessor rather than to the bidders. Competition turns higher (or lower) lease values resulting from general information into higher (or lower) cash bonuses which accrue to the lessor. Since the issue at hand is the impact of information (specifically, that produced from adjacent tracts - as will be discussed later) on lessors, the impacts of general information are most relevant.

When discussing the implications of increased general information, one is tempted to treat the quantity and extraction costs of the resource as given (or at least independent of the amount of information) and conclude, therefore, that information affects only rent distribution. One should resist that temptation. While the total supply of hydrocarbons in place is fixed (at least for now), the portion of that supply which will eventually be developed through leasing need not be. It seems likely that the volume of acreage offered for lease should depend (even for notoriously poor profit-maximizers like the federal government) on the prices received for those leases.

Moreover, even if the total supply of leases is fixed, the intertemporal scheduling of their development need not be. Given a distribution of tracts with different development and production costs, the present value of production from the entire group of tracts is increased by first leasing tracts with low (per-unit) development costs. Better information allows the lessor to identify low development-cost tracts and to sequence the leasing of individual tracts more efficiently. In the absence of perfect capital markets, this results in a benefit to society generally, as well as to the lessor.

Most of these benefits of information have been recognized implicitly, if not explicity, in the literature discussing oil and gas leasing. Undoubtedly, past proposals for general information production by lessors prior to sales reflect that recognition (see Mead et al., 1982).

Lastly, consider the effect of additional general information distributed unevenly among prospective bidders. Some authors have argued that this situation, termed asymmetric information, reduces payments to the lessor (Mead et al., 1982). Under cash-bonus auctions, the lessor's payment depends in part on the efficacy of competition. If bidders recognize the asymmetric distribution of information, those with relatively little information also should recognize their bidding disadvantage. In an English auction, for instance, in the extreme case where their competitors know the value of the tract and they do not, they can only win the bid by overbidding. Consequently, they have little incentive to participate actively in the bidding. If they underbid, they lose the lease. If they overbid, they win the lease but lose money. Under these circumstances, bidders with superior information can, in the absence of competition from uninformed bidders, obtain tracts at bargain prices. 
The importance of this argument is magnified by the typical nature of information production in oil and gas leasing. Inasmuch as information is usually generated by individual companies, it is likely, at least initially, to be asymmetrically distributed among prospective bidders. ${ }^{9}$ Again, this effect is more than just a question of rent redistribution. If asymmetric information inhibits competition, and thus reduces payments to lessors, leases may be supplied at a sub-optimal rate. ${ }^{10}$

\section{Information and Externalities}

In the case of a single lessor of neighboring tracts, informational effects need not create any allocation problems. To the extent that information created by adjacent drilling creates positive or negative benefits, the effects redound to the lessor through their impact on lease payments. Consequently, impacts of information which are external with respect to tract boundaries are internalized by the lessor.

However, if adjacent tracts are o!vned by different lessors, the activities which generate information on one lessor's tract may create external effects (positive or negative) on the value of neighboring lessors' tracts.

The direction of the externality depends upon the impact of information. By reducing development cost, cutting start-up time, decreasing risk, or improving scheduling, information generated by activities of one lessor might confer positive externalities on other lessors with tracts overlying the same geological structure. If, on the other hand, information produced on one tract spoils competition on adjoining tracts because of resulting asymmetries in information endowments, the initial lessor confers a negative externality on adjoining lessors.

The relative importance of the two types of externalities should depend, in large part, on the extent to which the initial producer of information can retain it privately. If he can retain it, the initial lessee realizes the benefits associated with the information when it comes time to produce adjoining tracts. Competition to be the initial lessee will capitalize those benefits in the form of higher payments to the first lessor. Thus, the value of prospective benefits on adjoining tracts is captured by the initial lessor in higher lease payments, and the positive (potentially external) effects of the information are internalized.

On the other hand, to the extent that private retention of information increases the asymmetry among bidders, it creates a negative externality. By spoiling competition, asymmetric information results in bargain prices for tracts adjacent to the lessee possessing the informational advantage. Competition to be that lessee (and to obtain second-round bargains) should transfer that benefit to the initial lessor. In this case, then, the value of the initial lessor's tract increases at the expense of his neighbors.

As private retention of information becomes more difficult-i.e., public dissemination becomes more costly to prevent - positive externalities become more likely. Because of public dissemination of information, benefits of the initial lessor's activity will tend to will be passed on to the second lessor in higher bonuses resulting from competitive bidding. Moreover, since public dissemination reduces the resulting asymmetries, second-round competition is less likely to be spoiled. Consequently,

9. This asymmetric distribution of information explains why Coase Theorem solutions (l.e., predevelopment unitization) may not solve the problem.

10. This heuristic statement of the problem involves considerable simplification relative to a complete analysis of the market equilibrium. 


\section{the severity of negative externalities should be reduced.}

Although ultimately the degree of private information retention is an empirical question, casual observation favors the public dissemination hypothesis. Common lore in the industry is that there is no such thing as a "tight hole." That is, information about a new discovery always leaks out. Moreover, in the case of federal leases, well logs from exploratory drilling must be filed with the federal government. Although the information is not released to other prospective competitors, the government itself uses the logs to form reservation price estimates to be used in evaluating bids. In effect, the government enters the market as a second informed bidder. The one informed private bidder may not be able to get away with a bargain price.

The relevance of these questions goes beyond academic interest. With the passage of the 1978 amendments to the Outer Continental Shelf Lands Act [43 U.S. Congress, 1337 (q)], the question assumes policy relevance. Section $8 \mathrm{~g}$ of the amendments calls for a "fair and equitable" distribution of revenues received from federal leases adjoining state lands. In State of Texas $v$. Watt, the court decided that fair and equitable distribution did indeed encompass compensation for external infor mation effects."

Economists typically have little to say about the terms "fair" and "equitable." One interpretation familiar to economists, is that lessors be paid according to the marginal value of their resources from society's standpoint. To reiterate a point made above, the issue is more than just one of rent distribution. If resource owners" supply of leases is price elastic, the socially optimal supply of leases is provided only if lessors receive the marginal social value of their leases at each date.

To the extent that significant externalities are present, either positive or negative, the present cash-bonus auction system may not provide the correct incentives to offer leases in areas with adjoining land ownership. If initial leases produce information that increases the market value of subsequent adjoining leases, landowners of neighboring leases have an added incentive to delay leasing-hoping their neighbors will go first. If, on the other hand, the first lessor captures the rents resulting from spoiled competition in subsequent auctions, lessors have an incentive to speed up leasing.

III. MEASUREMENT OF INFORMATION EXTERNALITIES IN OIL AND GAS LEASING

\section{A. Background Settings for Empirical Testing}

The federal government maintains records on many aspects of its OCS leasing program. Those records, including tabulations of bonus bids, production histories, and royalty payments, are publicly available through the Minerals Management Service. In addition, states conducting offshore oil and gas leasing programs generally keep some publicly available summary information. As a result, there was sufficient information available with which to test the hypothesis described above. Two settings were examined.

The first involved leasing by the federal government and Texas along their common offshore boundary. ${ }^{12}$ The setting corresponds well with the theoretical problem described above-different landowners issuing leases for exploration on adiacent tracts. The Texas/ federal boundary demarcates two large (over 700,000 acres) adja-

11. Memorandum Opinion and Onder, State of Texas o. Secretary of the Interior, et al., Civil Action No. B-79-476-CA, U.S. District Court for the Eastern District of Texas, Beaumont Division.

12. A line three leagues from the Texas shoreline. 
cent areas. If, in fact, information flows create external effects on lease payments, the sample is certainly of sufficient size to detect them. An added advantage is that, until recently, most of the information production (that is, exploratory activity) has occurred on the Texas side of the boundary. If the analysis reveals no effects on neighboring lease payments, we can at least rule out the possibility that despite the absence of measurable effects, information does create external effects which were obscured because of information flowing in both directions.

It is useful to compare payments per unit of resource as well as lease payments. However, close to half of the federal leases near Texas were issued after 1978. Inasmuch as production typically takes place on a given tract over a period of 12 years or more, we have little information concerning production, and therefore payments per unit of resource, from most adjoining federal leases in this sample. In order to examine the effect of information on per-unit payments, we studied a second setting.

In the past, the Department of Interior has sought to expedite leasing of tracts subject to drainage by adjoining tracts. To aid in this task, the Department employs a system of tract classification. Tracts are labeled "wildcat" if they do not adjoin known producing areas and "drainage" if they do. The importance of these classifications for this study is that drainage tracts (by definition) are leased subsequent to the emergence of (positive) information from an adjacent tract. Because the drainage/ wildcat classifications have been employed since the start of the OCS leasing program, it is possible to examine the ex post impact of information by making use of tracts' entire production history. That is, one can compare payments per unit of eventual production for wildcat and drainage leases and determine after the fact whether information produced from an adjoining discovery leads to higher or lower payments per unit of resource.

\section{B. Informational Impacts on Per-Acre Cash Bonuses}

The state of Texas began offshore leasing in 1947. For the most part, the state issued cash-bonus/fixed-royalty leases. ${ }^{13}$ Leases contained fixed-royalty rates (onesixth in early years, one-fifth more recently) and cash-bonus bids tendered in sealedbid auctions.

The state took several steps to encourage rapid leasing and development of its offshore tracts. In each sale, the state offered all tracts in which companies had expressed interest. In most instances, it divided standard-sized tracts (5,760 acres) into quarter sections ( 1,440 acres). It accepted all high cash-bonus bids above $\$ 25$ per acre-a nominal amount by offshore lease standards. Leases contained relatively short completion clauses, generally five years. Leases reverting back to the state after five years were then leased again. In short, the state offered large volumes of acreage in small tracts (reducing the size of initial investment), accepted (the resulting) low bids and stood ready to terminate and re-offer leases for tracts that were not developed.

One result of this program was that the state's offshore lands near the federal boundary were quickly developed. The three-mile strip landward of the boundary encompasses roughly 700,000 acres. According to state tabulations of leased acreage (see Submerged Lease Data, Volume 67), by 1965 (18 years after its leasing program

13. More recently, however, Texas has, in some cases, opted for royalty bidding (that is, bids stated in terms of royalty rate to be paid), especially with tracts which are expected to be highly productive. 
began), the state had issued leases (or re-leases) for 625,000 acres in or touching that three-mile strip. By 1975, the total had more than doubled to 1.3 million. As of 1981 , 2.3 million acres had been leased-each surface acre being leased, on average, three times.

On the federal side of the boundary, the pattern of development was quite different. The federal government offered less acreage in each sale. It participated actively in the bidding with a reservation price policy that not infrequently led to rejection of the high bid. Tracts were generally 5,760 acres and were seldom released.

As of 1981, according to Minerals Management Service reports, less than 500,000 total acres had been leased or re-leased in tracts touching the three-mile strip. Almost half of that total was leased after 1978.

FIGURE 1
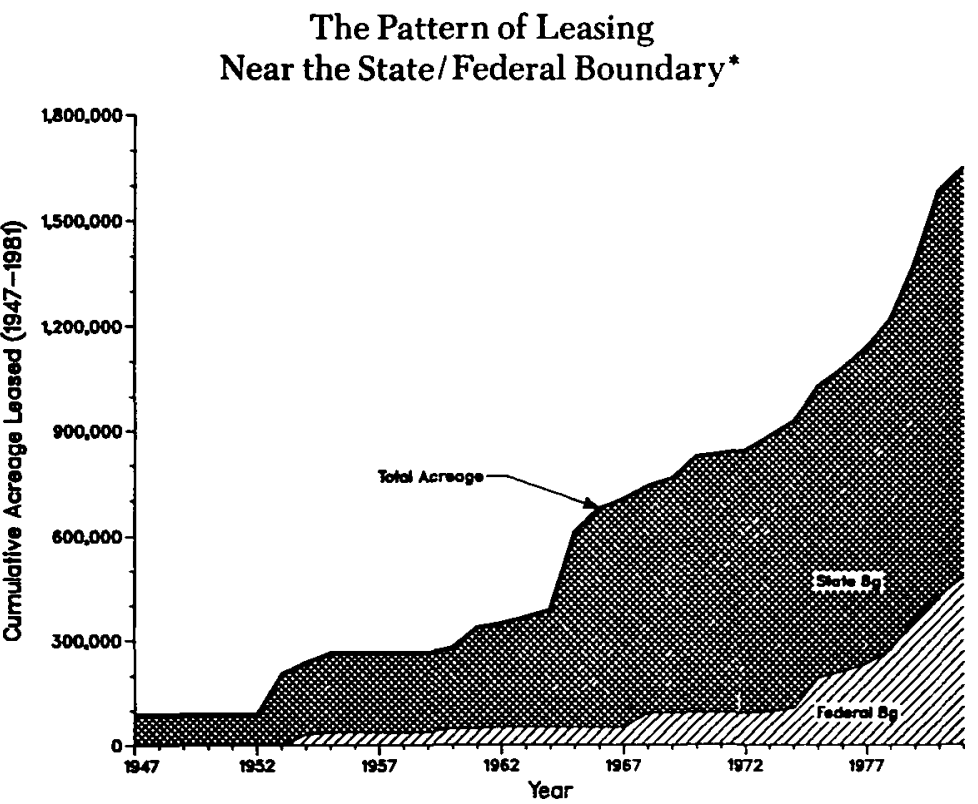

"Within three miles on either side of the three-league line. "State $8 \mathrm{~g}$ " and "Federal $8 \mathrm{~g}$ " refer to first-time oil and gas leases covered under section $8 \mathrm{~g}$ of the 1978 amendments to the federal Outer Continental Shelf Lands Act. That section calls for a "fair and equitable" distribution of rev'enues received from federal leases adjoining state lands.

SOURCES: State data are from the State of Texas General Land Office, Submerged Lease Data, Vol. 67 . Federal data are from Minerals Management Service, LPR-10 lease data, July 1982.

Figure 1 illustrates the difference in the pace of leasing for first-time leases of each tract. Even apart from the state's vigorous re-leasing program, the state leased substantially more acreage at an earlier date.

Like state leases, federal leases generally incorporated fixed royalties (one-sixth of production revenue) and cash-bonus bidding. To the extent that prior development 

bonuses. Everything else the same, that impact should be revealed by a per-acre comparison of bonuses on the state side with bonuses on the federal side.

From 1954 to 1981 , the state of Texas received, on average, $\$ 86$ per acre for leases near the state/federal boundary." Over that same period, the federal government received, on average, $\$ 2,400$ per acre for leases on its side of the line.$^{15}$ Going first, Texas leased over two million acres in its three-mile strip landward of the border and received $\$ 196$ million in cash bonuses. ${ }^{16}$ Going second, the federal government leased less than 500,000 acres in the area seaward of the boundary. Yet it received $\$ 1.1$ billion in cash bonuses."

Some of the difference may be due to factors other than information. State tracts were leased at an earlier date. Bidders for state tracts therefore may have had different expectations concerning natural gas prices than did federal bidders. Unfortunately, the direction of the difference is not obvious. Bidders in the 1950 s and early 1960s probably did not expect the rapid increase in natural gas prices during the early 1970s. If they did not, early state leases should have had relatively low bonuses. However, it also has been suggested that bidders in the late 1960s and early 1970s expected near-term decontrol of natural gas prices. ${ }^{18}$ Their bids therefore would have been higher, ceteris paribus, than those offered later in the 1970 s by bidders correctly expecting continued controls. In any case, the difference in lease date does not appear sufficient to account for differences in bonus payments of 30-to-1.

The differences may also reflect different royalty rates. In later leases, state royalty rates were four percentage points above federal rates. Moreover, the state often switched to royalty bidding for very productive tracts. Therefore, per unit of production, the difference in effective royalty rates may have been higher than four points. Higher royalty rates should reduce bonuses. Again, however, this factor would not seem sufficient to explain the observed differences. One study performed by the Department of Interior suggested that doubling royalty rates from 16.6 to 33 percent would reduce bonuses by 25 percent. ${ }^{19}$

Finally, the Department of Interior's active reservation price policy may explain some of the difference. The Department evaluated each tract prior to accepting any bids. High bids were compared with estimated tract values. Only high bids that were above (or sufficiently close to) estimated values were accepted. The avowed purpose of the program was to act as a check on competition. If, in fact, competition would not have been sufficiently strong in the absence of the program, tract evaluation may have increased bonuses. In that case, since the state did not engage in tract evaluation, state bonuses would have been lower than federal bonuses.

In light of these difficulties with interpretation, another approach to per-acre bonus comparisons was employed. Average per-acre bonuses for federal leases near

14. Texas, Submerged Lease Data, Vol. 67, pp. 1-102.

15. Minerals Management Service (1982).

16. Texas, Submerged Lease Data Vol. 67, pp. 1-102; Minerals Management Service (1882).

17. Minerals Management Service (1982).

18. Decontrol measures were under consideration by Congress in the late 1960 s and early 1970s.

19. Texas v. Watt et al., Exhibit 78E. 
Texas were compared with average per-acre bonuses for federal leases in the same lease sales farther offshore.

Since this comparison involves leases that were contemporaneous, problems arising with comparisons over time disappear. Furthermore, since the comparison involves only federal leases, lease terms and auction systems are identical.

\section{FIGURE 2}

\section{Per-acre Cash Bonuses in Federal Leases Offshore} and Leases Near the State Boundarv*

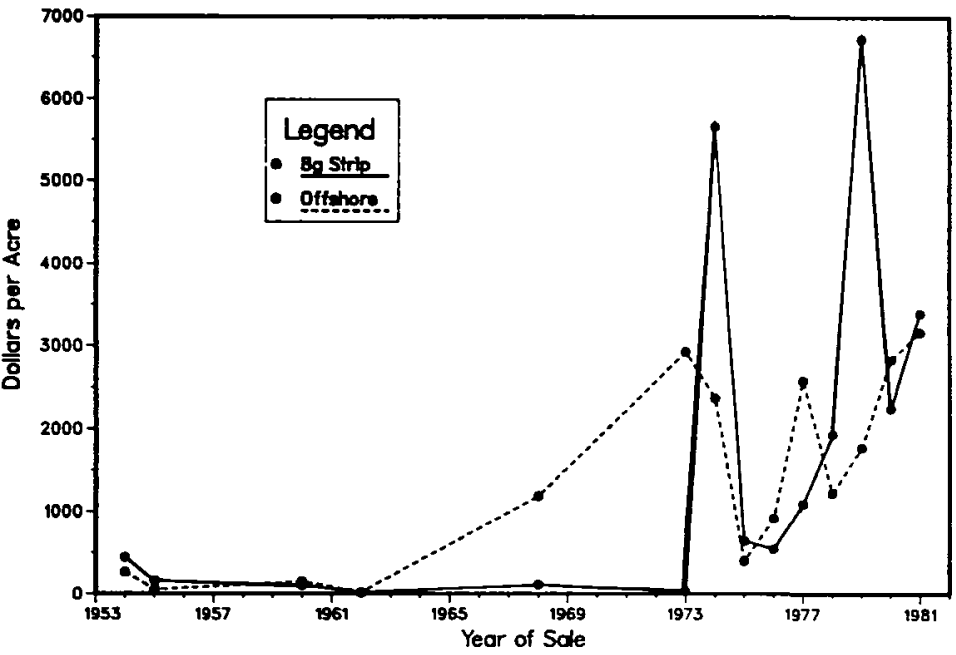

"The "8g Strip" refers to federal leases near the state/federal boundary off the Texas coastline. These leases are subject to section $8 \mathrm{~g}$ of the 1978 amendments to the federal Outer Continental Shelf Lands Act. "Offshore" refers to federal leases farther offshore, well beyond the state/federal boundary for oil and gas leasing.

SOURCE: Minerals Management Service, LPR-5 and LPR-10 data, July 1982.

Figure 2 shows annual average per-acre cash bonuses for leases offshore and near Texas. In early years, leases near Texas received consistently low per-acre bonuses (corresponding closely with average bonuses concurrently being received on the state side). Due to discoveries and resulting high bonuses farther offshore, offshore leases during the 1960s and early 1970s earned more per acre than leases offered near Texas. Through the mid-1970s, there was little change in the results of exploration on the federal side of the line near Texas. ${ }^{20}$ However, on the state side of the boundary several highly productive wells were discovered. The significant increases in average cash bonuses for federal leases near Texas beginning in 1975 (figure 2) are attributable to large bonuses paid for individual leases adjoining productive state tracts. One

20. Both the ratio of productive leases to total leases offered and the value of production per acre remained unchanged from the figures for earlier years. 
federal lease adjacent to the most productive state well received a cash-bonus bid of $\$ 153$ million-almost $\$ 36,000$ per acre."1

Over the entire period, 1954-1981, offshore Texas leases ${ }^{\text {s }}$ received an average bonus of $\$ 1,650$ per acre. ${ }^{\$}$ Leases near the boundary (and the state activity) received $\$ 2,540$, over 50 percent more bonus per acre. ${ }^{24}$ From 1975 to 1981 , the time during which 80 percent of the acreage near the boundary was leased, leases near Texas earned more than twice as much bonus as leases offshore $(\$ 3,080$ vs. $\$ 1,530) .^{25}$ In four federal lease sales (1979 to 1981), per-acre bonus comparisons between tracts near Texas and tracts farther offshore suggest that as much as half of the $\$ 1$ billion in cash bonuses paid to the federal government was due to informational effects.

Although the 2-to-1 factor revealed by these comparisons is certainly significant, it is an order of magnitude below the 30-to-1 ratio resulting from federal/state comparisons. The difference deserves some comment. The earlier lease dates, the bidacceptance rules, and the higher royalty rates characteristic of state leases all probably served to reduce state bonuses. Therefore, comparisons of contemporaneous federal leases (having the same royalty rates and issued under the same acceptance rules) should reduce observed differences in bonuses.

One problem with comparisons of per-acre bonuses is that those comparisons are meaningful only to the extent that the amount of acreage leased remains unaffected by emerging information. For instance, it might be argued that if expectations concerning resource values were rational (accurate on average) to begin with, information would serve mainly to shift cash bonuses from unproductive tracts to productive ones. The sum of cash bonuses offered would remain the same. This is the same zerosum logic mentioned above, which is advanced in support of the notion that increased general information has no value. According to the argument, per-acre comparisons incorrectly indicate increased overall bonuses due to added information because they overlook the zero bonuses on tracts that otherwise would have received bids. These zero bonuses also result from added information.

Our research suggests that despite its intuitive plausibility, this argument is not borne out by the facts. The frequency of tracts receiving zero bids was as high or higher farther offshore Texas as it was near the state, despite the differences in neighboring pre-sale development activity." From 1979 to 1981,10 of 52 (or 19 percent) of the tracts offered for lease near developed state lands received zero bids. At the same time, 41 of 146 (or 28 percent) of the tracts offered farther offshore received zero bids. ${ }^{2}$

This suggests that the effects of information on bidders' expectations may not be symmetric. That is, while a successful discovery may increase interest in adjacent

21. Minerals Management Service (1982).

22. Beyond three miles seaward of the three-league state/federal boundary.

23. Minerals Management Service (1982).

24. Ibid.

25. Ibid.

26. Ibid.

27. The possibility still remains that due to negative information, tracts that otherwise would have been leased were never included in lease sales.

28. Minerals Management Service (1982). 
tracts, a dry hole need not eliminate that interest. ${ }^{9}$ This view of information effects is not implausible. There is a wide variation in the size of individual hydrocarbon deposits. Because of the presence of large deposits, a discovery in one tract should increase the prior probability of a discovery on adjoining tracts. However, because of the presence of smaller deposits, a dry hole in one tract need not eliminate the prior probability of finding hydrocarbons on adjoining tracts. As a result, it would not be surprising if increased information, even increased negative information, did not reduce the number of tracts leased. If so, comparisons of average per-acre bonuses for all tracts leased provide useful measures of informational effects.

C. Informational Impacts on Payments Per Unit of Production

Does information lead to increased payments per unit of resource recovered? The theory suggests that information should lead both to higher total payments and to higher payments per unit. Through its effect on production costs, information should lead to higher values for any given volume of resource and, to the extent the information becomes public, higher market payments per unit of resource.

To obtain estimates of payment per unit, we compared federal drainage and wildcat leases issued prior to 1971 offshore both Texas and Louisiana. We used only federal leases because data concerning production revenue was not readily available for state leases. The 1970 cutoff reflects a typical productive lease lifetime of about 12 years. ${ }^{30}$ As described above, the grouping of drainage versus wildcat is intended to capture differences in bidders' prior information. Since these government classifications are public, information they contain should be reflected in bidders' expectations.

Cash bonuses per dollar of nominal production value are reported for drainage and wildcat tracts in table 2 below. The table also compares cash bonuses per dollar of production value for producing leases alone.

TABLE 2

Cash Bonus Per Dollar of Nominal Production Value, 1954-1970

\begin{tabular}{lcc} 
& All Leases & Producing Leases \\
Wildcat Leases & $\$ 0.103$ & $\$ 0.063$ \\
Drainage Leases & 0.117 & 0.103 \\
\hline
\end{tabular}

SOURCE: Minerals Management Service, LPR-10 data.

For all tracts, drainage and wildcat leases received about the same cash bonus per dollar of (eventual) production. Restricting the comparison to producing tracts reveals that drainage leases earned almost 65 percent more per dollar of production value than did wildcat leases.

The two comparisons can be thought of as representing two extreme cases. The difference in the results reflects the impact of the large portion of wildcat tracts that were not productive. ${ }^{31}$ As can be seen in the table above, whether or not you receive

29. This description comports well with testimony in Texas $v$. Watt. See Direct Testimony of P. G. Von Tungelen and John Rankin. Experts on oil and gas bidding offered by both sides testified that tracts are not condemned by adjacent dry holes.

30. Minerals Management Service (1982).

31. There were also some unproductive drainage tracts; however, this occurred much less frequently. 
more bonus per dollar of production value by going second depends in part upon how information affects the frequency of bonuses for nonproducing wildcat leases. At one extreme, if information resulting from prior activity eliminates bids for all nonproducing tracts on the second round, going second is equivalent to trading wildcat leases for (fewer, more productive) drainage leases. There is little net effect on cash bonus per production dollar. At the other extreme, if prior dry holes do not condemn adjacent tracts, lessors receive bids on nonproducing wildcats whether they go first or second. However, by going second the lessor receives the producing drainage tract payment rather than the producing wildcat payment for producing tracts. In that case, overall per-unit payments will be higher with the information.

The fact that in the extreme case, one is indifferent as to timing, while going second is preferred in all other cases suggests that information generated by prior activity generally does lead to higher payments per unit for the second lessor. Available evidence indicates that, on balance, dry holes do not condemn adjacent tracts. The gain to going second may be close to 65 percent more bonus per dollar of production.

These results are consistent with findings of previous research. In their 1980 study, Mead et al. (1980, p. 80) reported the results of a regression analysis applied to cash bids received for leases offshore Texas and Louisiana. The list of independent variables included the value of eventual production and a dummy variable according to whether the lease was drainage or wildcat. Since production was included, the coefficient on the dummy can be interpreted as the impact of drainage classification on payment per unit of production. The estimated coefficient, significant at the 95 percent level, suggests that payments per unit double for drainage leases.

\section{Information Asymmetry and Competition}

A 1981 report to the Department of Interior advanced the hypothesis (discussed above) that asymmetric information endowments would create a negative externality reducing second round lease payments (see Mead et al., 1982, p. 35). As empirical support for this hypothesis, they reported the results of research concerning internal rates of return. They found that internal rates of return to the lessee were higher (both before and after tax) on drainage leases than they were on wildcat leases. Since lessees retained a higher share of rent going second, lessors obtained a higher share going first.

The conclusion is opposite the one reached here. We conclude that from thestandpoint of informational effects, the lessor is better off going second, after initial exploration by the adjoining landowner-better both in terms of cash bonuses per acre and in total payments per unit of production. If so, what of the difference in the lessee's internal rates of return? Assuming that their calculations for after-tax rates of return are correct, the answer probably lies with costs. As argued above, better information about the size and location of hydrocarbon deposits should reduce perunit production costs-if only because of resources saved on dry holes. Materials produced in State of Texas $v$. Watt suggest that per-unit costs in drainage leases may be as low as 60 percent of per-unit wildcat costs.

If, in fact, per-unit costs with information are substantially below per-unit costs without it, the reconciliation of our results with the Mead et al. (1982) rate-of-return studies is straightforward. Because of its effect on lower per-unit costs, information increases the total economic rent per dollar of production. Since there is more rent in total, the Mead et al. (1982) finding that lessees retain more rent, given better information, is not inconsistent with our finding that in those same leases the lessor also 
receives more rent. Because of the existence of information, the overall pie is bigger. Apparently both parties receive a larger slice.

\section{CONCLUSION}

In the Gulf of Mexico, information derived from prior development increased the payments received by lessors of adjoining tracts. As a result, lessors who paid for the initial information development through lower cash bonuses may have faced suboptimal incentives to develop the Outer Continental Shelf. By either interpreting the "fair and equitable" standard in the 1978 OCS Lands Act Amendments to include informational effects, incentives faced by lessors are brought more in line with the social value of development activity. Unless the supply of oil and gas leases is completely price inelastic, such a policy should increase economic efficiency.

\section{REFERENCES}

American Petroleum Institute, Statistics Department, Washington, D.C., 1979 Joint Association Survey on Drilling Costs, February 1981 ed., Table 53.

Leland, H. E., Nordgaard, R. B., and Pearson, S. R., An Economic Analysis of Alternative Outer Continental Shelf Leasing Policies, Report to the National Science Foundation, 1975.

Mead, W. J., Sorensen, P. E., Jones, R. O., and Moseidjord, A., Competition and Performance in OCS Oil and Gas Lease Sales and Lease Development, 1954-1969, U.S. Geological Survey Contract No. 1408-0001-16552, March 1, 1980.

Mead, W. J., Sorensen, P. E., and Moseidjord, A., Competitive Bidding Under Arymmetric Information, U.S. Geological Survey Contract No. 14-08-0001-18678, January 31, 1982.

Miller, E., "Some Implications of Land Ownership Patterns for Petroleum Policy," Land Economics, November $1973,49,415$.

Minerals Management Service, LPR-5 and LPR-10 data, July 1982.

Peterson, F. M." "Two Externalities in Petroleum Exploration," in G. M. Brannon, ed., Studies in Energy Tax Policy, Ballinger Publishing Co., Cambridge, Mass., 1975.

State of Texas General Land Office, Submerged Lease Data, Vol. 67.

State of Texas v. James G. Watt, et al., Civil Action No. B-79-476-CA, U.S. District Court for the Eastern District of Texas, Beaumont Division.

State of Texas 0 . Secretary of Interior, et al., Memorandum Opinion and Order, Civil Action No. B-79476-CA, U.S. District Court for the Eastern District of Texas, Beaumont Division.

Stiglitz, J. E., "The Efficiency of Market Prices in Long Run Allocations in the Oil Industry;" in G. M. Brannon, ed., Studies in Energy Tax Policy, Ballinger Publishing Co., Cambridge, Mass., 1975. Wilson, R. B., "Competitive Bidding with Asymmetric Information," Management Science, July 1967, $13,816-820$.

Reproduced with permission of the copyright owner. Further reproduction prohibited without permission. 